\title{
MODEL OPTIMISASI LOT PRODUKSI DENGAN PERTIMBANGAN BIAYA KUALITAS PADA SISTEM PRODUKSI MULTISTAGE
}

\author{
Arie Desrianty ${ }^{1}$, Hendro Prassetiyo ${ }^{2}$ Ladzwina Mahardini $^{3}$ \\ Jurusan Teknik Industri Institut Teknologi Nasional ${ }^{1,2,3)}$ \\ Bandung, Indonesia ${ }^{1,2,3)}$ \\ E-Mail : adesrianty@itenas.ac.id
}

\begin{abstract}
Deterioration problem is due to a decrease in engine performance the machine used constantly. Deterioration of the engine can cause production system problem. In this research, the development of optimization models taking into account the production and quality cost component in the multistage production system. All products will undergo inspection by sampling or census. Good product after sampling inspection will be delivered to the consumer, while the nonconforming product will be inspected prior to the census carried out rework. Dynamic programming used to optimize the decision-making process over the entire stage which was later named the optimal policy.
\end{abstract}

Keywords : Deterioration, Multistage, Non Conforming Item, Production Lot.

\section{PENDAHULUAN}

Salah satu model yang digunakan untuk menentukan ukuran jumlah produksi adalah model Economic Production Quantity (EPQ). Pada model EPQ diasumsikan fasilitas produksi yang digunakan tidak pernah mengalami kegagalan sehingga seluruh produk yang telah dihasilkan selalu berkualitas baik dan dapat diterima (Tersine, 1994). Pada kenyataannya sebuah system produksi dapat berada dalam kondisi yang tidak sempurna. Rosenblatt \& Lee (1986) menyatakan bahwa dalam suatu produksi yang tidak sempurna (imperfect) akan menghasilkan produk yang baik dan produk yang cacat. Cacat pada produksi dapat disebabkan oeh beberapa faktor, antara lain operator, proses, material, dan mesin. Mesin produksi yang digunakan tidak stabil karena mengalami deteriorasi.

Deteriorasi mesin dapat terjadi karena pemakaian dan atau karena penuaan (Ebeling, 1997). Ben-Daya \& Rahim (2003) mempertimbangkan bahwa kondisi produksi yang tidak sempurna dapat terjadi juga karena adanya kesalahan dalam inspeksi, yaitu terjadi probabilitas untuk menerima produk yang cacat dan probabilitas menolak produk yang baik.
Wibowo (2014) telah melakukan pengembangan model untuk penentuan lot produksi pada sistem produksi yang tidak sempurna akibat masalah deteriorasi dan kesalahan inspeksi sampling. Model tersebut membahas sistem produksi yang terdiri dari satu stage, padahal pada kenyataannya banyak industri manufaktur yang menggunakan lebih dari satu stage pada proses produksinya.

Tujuan dari penelitian ini adalah mengembangkan suatu model optimisasi penentuan lot produksi untuk kasus single item dan multi stagepada sistem produksi yang mengalami deteriorasi dan kesalahan inspeksi dengan kriteria minimisasi total ongkos. Pada model ini dipertimbangkan biaya kualitas yang terlibat selama proses produksi. Formulasi optimisasi menggunakan programa dinamis probabilistik dengan jumlah run produksi yang terbatas. 


\section{METODOLOGI PENELITIAN}

Sistem yang dibahas pada penelitian ini adalah sistem produksi multi stage tidak sempurna yang mengalami deteriorasi dan kesalahan inspeksi sampling. Menurut Jhonson dan Montgometry (1974) untuk menggambarkan beberapa karakteristik dari model multistage,

ketika permintaan dan faktor lain berubah seiring waktu dapat dilihat pada gambar 1 .

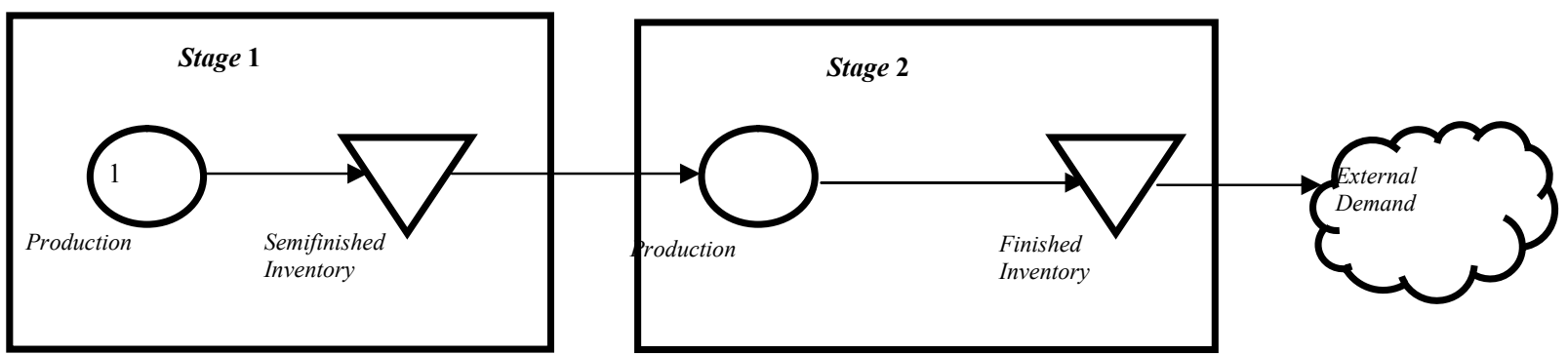

Gambar 1. Sistem Persediaan yang Diproduksi pada Dua Stage.

Produk yang diproduksi pada dua stage menghasilkan satu produk jadi. Plant (Departemen) pertama memproduksi produk setengah jadi, dan penyimpanan barang tersebut. Plant (Departemen) kedua merupakan penyelesaian produk setengah jadi menjadi produk jadi, dan penyimpanan produk jadi tersebut, dimana permintaan terhadap barang tersebut tidak dapat ditentukan waktunya.

Menurut Hiller (1995), programa dinamis merupakan suatu teknik matematisuntuk pembuatan serangkaian keputusan yang saling berhubungan, sedangkan menurut Taha (1992), definisi programa dinamis adalah suatu teknik matematis yang dirancang terutama untuk mengembangkan efisiensi perhitungan dari persoalan menjadi masalahyang lebih kecil sehingga perhitungannya akan lebih mudah diselesaikan. Dalam pemecahan masalah dengan menggunakan programa dinamis tidak terdapat suatu rumusan matematis yang standar. Tetapi programa dinamis merupakan suatu tipe pendekatan umum dalam pemecahan masalah dan persamaanpersamaan tertentu yang digunakan harus dibuat sesuai dengan situasi yang ada.

Ciri - ciri pemrograman dinamis adalah sebagai berikut :

- Permasalahan dapat dibagi dalam tahaptahap (stages).
- Setiap tahap (stage) memiliki sejumlah keadaan (states) yang bersesuaian.

- Pengaruh keputusan kebijakan pada setiap tahap adalah untuk mengubah keadaan sekarang menjadi keadaan yang berkaitan dengan tahap berikutnya.

- Prosedur penyelesaian dimulai dengan menemukan kebijakan optimal untuk tahap terakhir.

- Terdapat hubungan rekursif yang mengidentifikasikan kebijakan optimal untuk setiap status pada tahap $n$, yang menentukan kebijakan optimal untuk setiap status dari $(n-1)$ tahap yang tersisa.

Pada penelitian ini, untuk pengujian model digunakan programa dinamis probabilistik. Pada programa dinamis probabilistik, status suatu tahap ditentukan oleh distribusi kemungkinan tertentu. Distribusi ini bergantung dari keputusan yang diambil pada tahap sebelumnya.

Langkah - langkah pengembangan model yang dilakukan adalah sebagai berikut

- Identifikasi model konseptual karakteristik sistem.

Model konseptual didasari berdasarkan model dasar yang dikembangkan oleh Ben-Daya \& Rahim (2003) dan Wibowo (2014). 
- Identifikasi notasi yang diperlukan. Identifikasi notasi ditentukan berdasarkan kebutuhan yang diperlukan dalam pengembangan model dengan ekspektasi total biaya.

- Penentuan formulasi model.

Mengubah model konseptual menjadi model matematis menggunakan notasi yang sudah ditentukan sesuai dengan fungsi tujuan.

- Pengujian model.

Pengujian menggunakan tahapan-tahapan pemrograman dinamis probabilistik.

\section{HASIL PENELITIAN}

Sistem yang dibahas dalam penelitian ini adalah sistem yang terdiri dari dua stage. Meskipun banyak masalah terjadi di dalam proses produksi, namun perusahaan harus tetap memastikan produk yang dikirim ke konsumen terpenuhi, tepat waktu, dan tidak cacat.

Permintaan konsumen yang tidak terpenuhi akan dikenakan biaya penalti. Permintaan konsumen telah terpenuhi namun produk yang dikirim adalah non conforming item, maka perusahaan dikenakan biaya complain oleh konsumen. Sistem penelitian dapat dilihat pada gambar 2 .

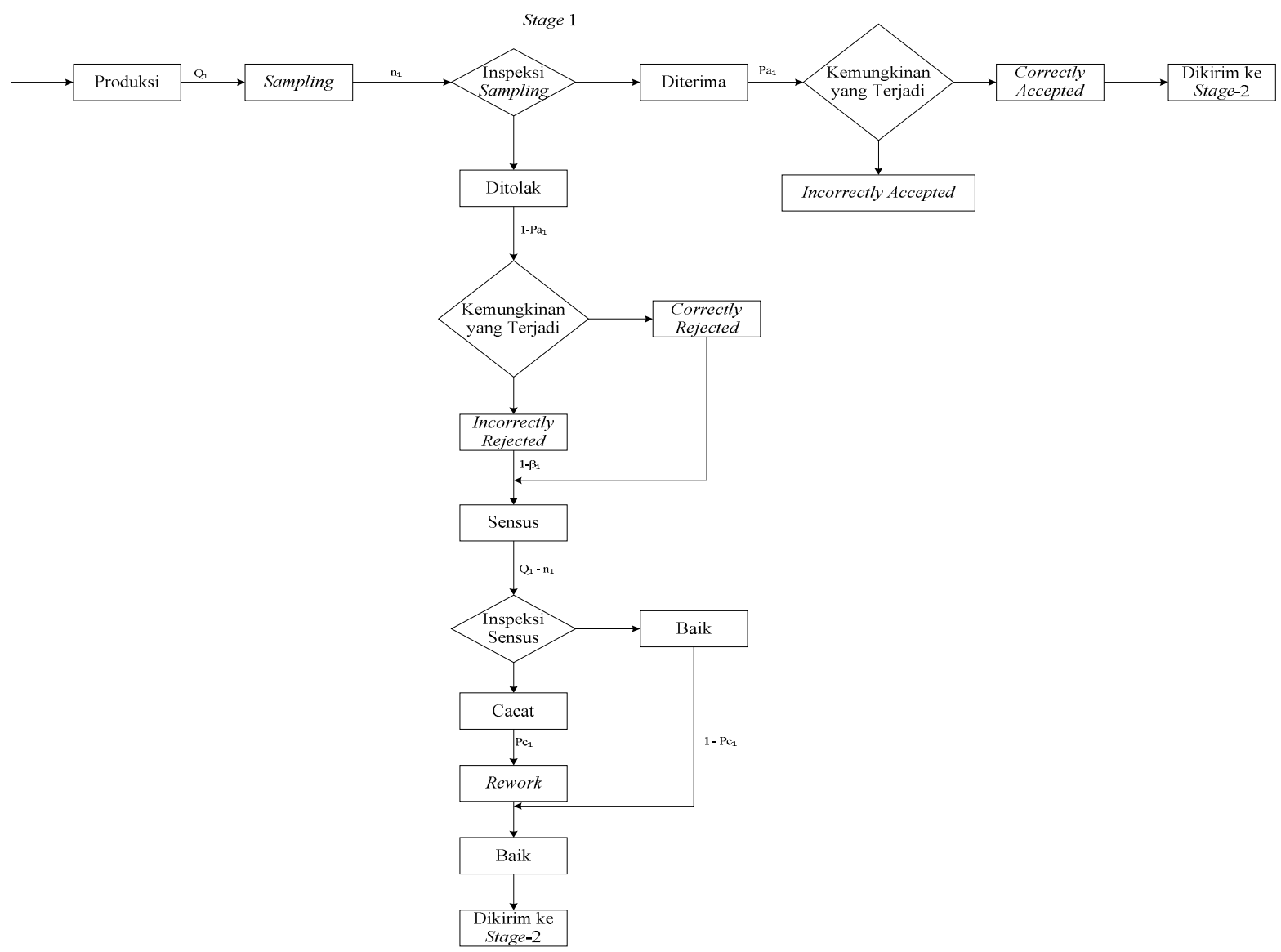

Gambar 2a. Sistem Penelitian 1. 


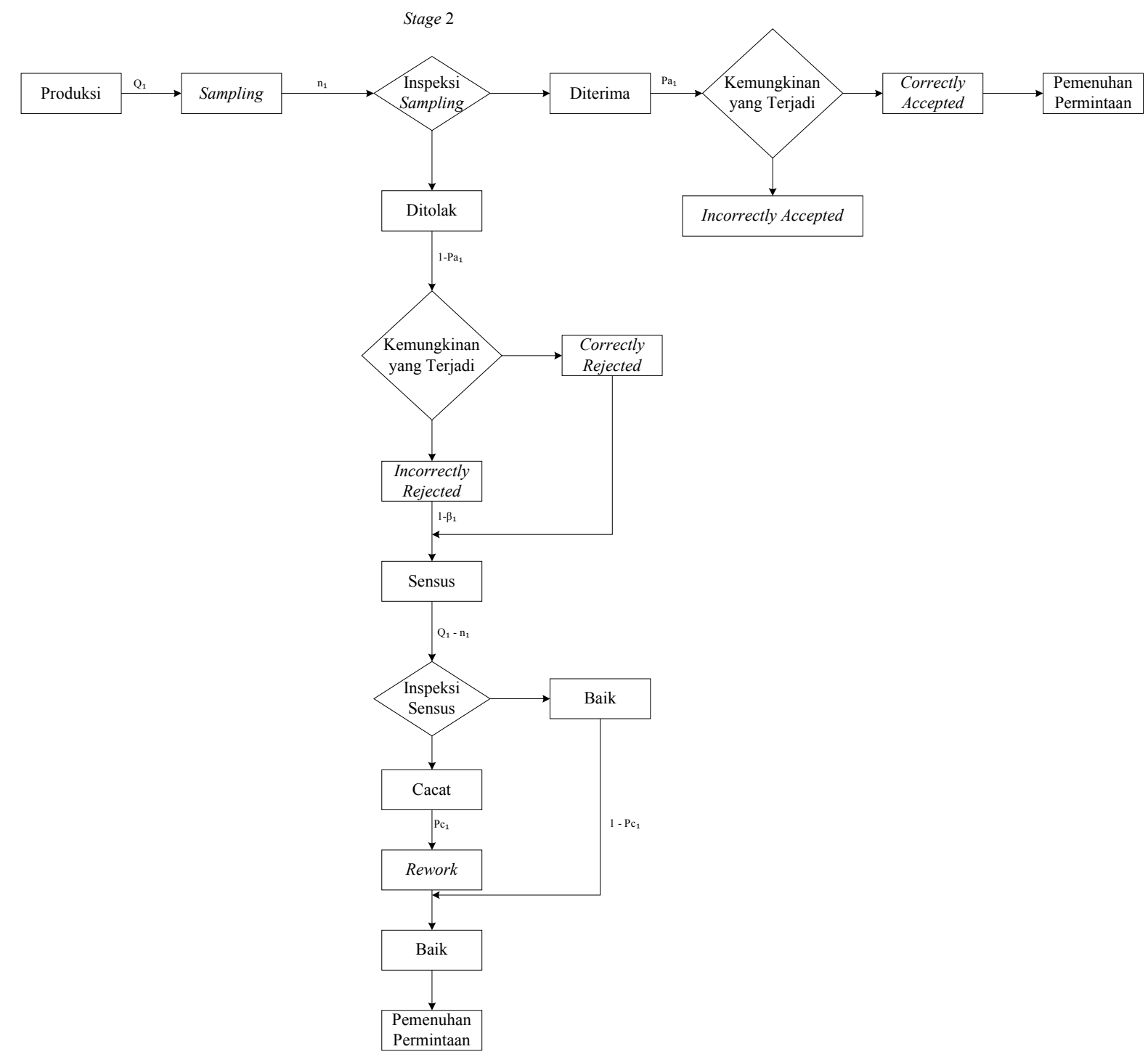

Gambar 2b. Sistem Penelitian 2.

Produk yang dibuat melewati proses inspeksi secara sampling. Bila keputusannya diterima, maka dilanjutkan ke proses selanjutnya. Bila ditolak maka akan dilakukan pemeriksaan secara sensus. Produk cacat yang ditemukan pada inspeksi sensus akan dilakukan rework. Hasil rework diasumsikan selalu menjadi produk baik. Produk akhir yang dinyatakan diterima langsung dikirim ke konsumen sebanyak (Qn), karena produk yang dijadikan sampel (n) tidak ikut dikirim ke konsumen. Produk yang menjadi sampel (n) tidak dikirim karena produk tersebut telah mengalami pengurangan kualitas akibat proses inspeksi. Pada proses pemeriksaan akan menghasilan dua kejadian yaitu produk baik dan produk gagal. Setiap kejadian akan menghasilkan dua kemungkinan yaitu, produk baik dapat diterima dan produk baik dapat ditolak, sedangkan untuk kejadian produk gagal akan menghasilkan produk gagal dapat diterima dan produk gagal dapat ditolak.

Pembuatan model membutuhkan notasinotasi yang bertujuan untuk memudahkan dalam penulisan dan pembacaan. Notasinotasi yang digunakan dalam penelitian ini adalah :

$$
\begin{aligned}
i & =\text { stage produksi, }(i=1 \text { atau } 2) . \\
j & =\text { run produksi, }(j=1,2,3, \ldots ., j) . \\
U_{1} & =\text { ongkos set-up di stage } 1 . \\
U_{2} & =\text { ongkos set-up di stage } 2 . \\
D & =\text { demand (unit). } \\
Q_{j} & =\text { ukuran lot produksi yang harus } \\
& \text { dibuat di run ke-j (unit). }
\end{aligned}
$$


$s_{j} \quad=$ permintaan konsumen yang masih harus dipenuhi di setiap run ke-j (unit).

$1-P c_{i j}=$ probabilitas produk baik di setiap stage ke- $i$ dan run produksi ke- $j$ $(\%)$.

$P_{c_{i j}} \quad=$ probabilitas produk cacat di setiap stage ke-i dan run produksi ke- $j$ $(\%)$.

$a \quad=$ probabilitas kenaikan jumlah produk gagal (\%).

$\theta_{1, j}=$ probabilitas kebenaran menerima conformingitem di stage ke- $i$ dan run ke-j.

$\theta_{i_{i j}} \quad=$ probabilitas kebenaran menolak conforming item di stage ke- $i$ dan run ke-j.

$\theta_{i_{i, j}}=$ probabilitas kebenaran menolak non-conforming item di stage ke- $i$ dan run ke-j.

$\theta_{4 i j}=$ probabilitas kebenaran menerima non-conforming item di stage ke- $i$ dan run ke-j.

$C_{1}=$ ongkos produksi di stage 1 (Rp/unit).

$C_{2}=$ ongkos produksi di stage 2 (Rp/unit).

$C_{3} \quad=$ ongkos inspeksi sensus distage 1 (Rp/unit/satuan waktu).

$C_{4}=$ ongkos simpan $(\mathrm{Rp} /$ unit/satuan waktu).

$C_{5} \quad=$ ongkos rework di stage $1(\mathrm{Rp} /$ unit /satuan waktu).

$C_{6} \quad=$ ongkos inspeksi sensus distage 2 (Rp/unit/satuan waktu).

$C_{7} \quad=$ ongkos rework di stage $2(\mathrm{Rp} /$ unit /satuan waktu).

$C_{9}=$ ongkos inspeksi sampling di stage 1 (Rp/unit).

$C_{9}=$ ongkos inspeksi sampling di stage 2 (Rp/unit).

$C_{10}=\operatorname{ongkos}$ complain (Rp/unit).

$t_{1}=$ waktu inspeksi sensus di stage 1 (satuan waktu/unit).

$\mathbf{t}_{2}=$ waktu reworkdi stage 1 (satuan waktu/unit).

$t_{7}=$ waktu inspeksi sensus di stage 2 (satuan waktu/unit).

$t_{4}=$ waktu rework di stage 2 (satuan waktu/unit).

$t_{5} \quad=$ waktu reworkuntuk produk incorrectly accepted di stage 1 (satuan waktu/unit).

$t_{\bar{\varepsilon}}=$ waktu inspeksi sampling di stage 1 (satuan waktu/unit).

$t_{\overline{7}}=$ waktu inspeksi sampling di stage 2 (satuan waktu/unit).

Akibat dari deteriorasi menyebabkan akan terdapatnya probabilitas produk baik dan probabilitas produk gagal. Probabilitas terjadinya produk cacat pada setiap run produksi dinotasikan dengan $P c_{i, j}$. Probabilitas kegagalan produksi ini akan terus naik akibat pengaruh dari laju kenaikan probabilitas produk gagal $(a)$ dan probabilitas produk gagal pada run ke- $j\left(P g_{0}\right)$. Dengan menggunakan model dalam Astria (2006), maka probabilitas kegagalan produksi yang mungkin terjadi di setiap run produksi ke-j adalah :

$P g_{j}=(1+a)^{j} x P g_{0}$

Probabilitas jumlah produk gagal diperoleh dengan menggunakan distribusi binomial sebagai berikut :

$b(x ; n ; p)=p^{x} \cdot q^{n-x}$

Biaya kegagalan yang dipertimbangkan pada penelitian ini terdiri atas biaya kegagalan internal dan eksternal. Biaya kegagalan internal muncul ketika sejumlah part tidak memenuhi spesifikasi kualitas sebelum batch ditransfer ke konsumen sedangkan biaya kegagalan eksternal terjadi jika batch yang dikirim ke konsumen ditolak oleh konsumen dan dikembalikan ke perusahaan. (Indrapriyatna et. al., 2008).

Biaya kegagalan internal mencakup :

- Biaya untuk memeriksa seluruh part yang belum diperiksa (sebab part itu tidak termasuk sampel).

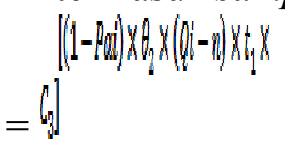


- Biaya simpan part selama pemeriksaan $100 \%$.

$$
=
$$$$
(1-P a i) \times Q i \times t_{1} \times
$$

- Biaya untuk mengerjakan ulang seluruh partnonconforming.

$$
=
$$

$$
(1-P a i) \times P r_{1} \times r_{1} \times t_{2} \times
$$

- Biaya simpan part selama pengerjaan ulang.

$$
=(1-P a i) \times Q i \times t_{2} \times
$$

Pada penelitian ini diasumsikan bahwa apabila terdapat produk cacat yang diterima konsumen, maka produk tidak dikembalikan melainkan perusahaan membayar biaya complain sebagai biaya kegagalan eksternal.

$$
\text { Biaya complain }=\quad P_{a i j} \times P_{r i j} \times r i j \times \ldots(7)
$$

Rumusan perhitungan total biaya yang digunakan pada penelitian ini terdiri atas biaya set-up, biaya produksi, serta biaya kegagalan internal dan eksternal yang terjadi pada stage 1 dan stage 2. Fungsi tujuan dari pemodelan ini adalah meminimisasi total pengeluaran biaya oleh perusahaan dengan persamaan sebagai berikut :

$T C=\left[U_{1} \mid U_{2}\right] \mid\left[\left(\left[\begin{array}{ll}0 & \left.\times Q_{1}\right)\end{array}\right)\right.\right.$

(a) $\times(2)]+\left[\left[\mathrm{n} \times t_{7} \times \mathrm{B}_{2}\right]+\right.$

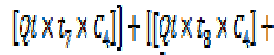

$\left.\left.\left[Q i \times t_{8} \times c_{4}\right]\right]\right)+\left[\left(\left[\left(1-P_{a}\right) \times\right.\right.\right.$

$\left.(0 i-a) \times t_{1} \times C_{3}\right]+\left[\left(1-P_{a j}\right] \times 0 i \times\right.$

$\left.t_{1} \times C_{4}\right]+\left[\left[(1-P u d) \times(0 i-n) \times t_{3} \times\right.\right.$

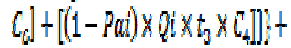

$\left(\left[(1-P a i) \times P_{1} \times r_{1} \times t_{2} \times c_{g}\right]+\right.$

$\left.\left[\left(1-P_{0} i\right) \times Q i x_{2} \times c_{1}\right]\right]+$

$\left[(1-P a d) \times P_{2} \times r_{2} \times t_{4} \times C_{7}\right)+$

$\left.\left((1-P u i) \times \theta_{4 i j} \times P_{l_{2}} x_{r_{2}} \times b_{3} \times G_{7}\right)\right]+$

$\left[(1-P c c) \times Q i \times t_{1} \times C_{1}\right]+\left[\left(1-P_{d x}\right) \times\right.$

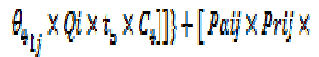

rij $\left.x C_{10}\right]$
Solusi optimal untuk ukuran lot produksi pada model penelitian ini didapatkan melalui tahapan pemrograman dinamis probabilistik sebagai berikut :

- Tahap.

Pengambilan keputusan ukuran lot produksi pada setiap run ke-j dinyatakan sebagai tahap pengambilan keputusan dengan $\mathrm{j}=1,2,3, \ldots, \mathrm{j}$.

- Variabel keputusan.

Variabel keputusan pada penelitian ini yaitu ukuran lot di setiap run produksi ke-j (Qj) pada sistem produksi yang tidak sempurna dengan kriteria minimisasi total cost.

- Status.

Status $(\mathrm{Sj})$ pada penelitian ini merupakan jumlah permintaan konsumen yang masih harus dipenuhi. Pemilihan keputusan status untuk run produksi ke-(j+1) dipengaruhi berdasarkan keputusan lot produksi diterima $(\mathrm{Tr})$ atau lot produksi ditolak (Tl) di run produksi ke-j. Struktur dari pemrograman dinamis probabilistik yang menunjukan hubungan antara status ditahap ke- $j$, keputusan $Q j$, probabilitas ke- $j$, dan status ditahap ke- $(j+1)$ dapat dilihat pada gambar 3 . 
Tabel 1 Nilai Parameter Set Data Pengujian

\begin{tabular}{c|c}
\hline Notasi & Nilai \\
\hline$t_{1} \& t_{3}$ & 1 \\
$t_{2} \& t_{4}$ & 2 \\
$T_{5}$ & 1 \\
$t_{6} \& t_{7}$ & 1 \\
$U_{1}$ & 10 \\
$U_{2}$ & 11 \\
$C_{1}$ & 5 \\
$C_{2}$ & 6 \\
$C_{3}$ & 2 \\
$C_{4}$ & 0,5 \\
$C_{5}$ & 1 \\
$C_{6}$ & 3 \\
$C_{7}$ & 2 \\
$C_{8}$ & 2 \\
$C_{9}$ & 3 \\
$C_{10}$ & 20 \\
\hline
\end{tabular}

Tabel 2 Probabilitas Kegagalan Produksi Inspeksi Sampling

\begin{tabular}{c|c|c|c|c}
\hline$j$ & $\begin{array}{c}\text { Jumlah } \\
\text { Produksi } \\
\left(q_{j}\right)\end{array}$ & $\begin{array}{c}\text { Ukuran } \\
\text { Sampel } \\
(n)\end{array}$ & $\begin{array}{c}\text { Probabilitas } \\
\text { Penerimaan } \\
\left(F_{\alpha i}\right)\end{array}$ & $\begin{array}{c}\text { Probabilitas } \\
\text { Penolakan } \\
\left(1-p_{\alpha i j}\right)\end{array}$ \\
\hline 3 & 4 & 2 & 0,67 & 0,33 \\
2 & 5 & 2 & 0,61 & 0,39 \\
3 & 4 & & & \\
\hline & 3 & 2 & 0,55 & 0,45 \\
\hline
\end{tabular}


Tabel 3. Probabilitas Kegagalan Produksi Inspeksi Sensus

\begin{tabular}{|c|c|c|c|c|}
\hline$i$ & $\begin{array}{c}\text { Jumlah } \\
\text { Produk } \\
(Q-n)\end{array}$ & $\begin{array}{c}\text { Jumlah } \\
\text { Produk } \\
\text { Cacat } \\
(x)\end{array}$ & $\begin{array}{c}\text { Probabilitas } \\
\text { Ditemukannya } \\
\text { Produk Cacat } \\
(P r i j)\end{array}$ & $\begin{array}{c}\text { Probabilitas } \\
\text { Ditemukannya } \\
\text { Produk Baik } \\
(1-P r i j)\end{array}$ \\
\hline \multirow{9}{*}{1} & \multirow{2}{*}{1} & 0 & 0,82 & 0,18 \\
\hline & & 1 & 0,18 & 0,82 \\
\hline & \multirow{3}{*}{2} & 0 & 0,67 & 0,33 \\
\hline & & 1 & 0,30 & 0,70 \\
\hline & & 2 & 0,03 & 0,97 \\
\hline & \multirow{4}{*}{3} & 0 & 0,55 & 0,45 \\
\hline & & 1 & 0,36 & 0,64 \\
\hline & & 2 & 0,08 & 0,92 \\
\hline & & 3 & 0,01 & 0,99 \\
\hline \multirow{9}{*}{2} & \multirow{3}{*}{1} & 0 & 0,78 & 0,22 \\
\hline & & 1 & 0,22 & 0,78 \\
\hline & & 0 & 0,61 & 0,39 \\
\hline & \multirow[t]{2}{*}{2} & 1 & 0,34 & 0,66 \\
\hline & & 2 & 0,05 & 0,95 \\
\hline & \multirow{4}{*}{3} & 0 & 0,48 & 0,52 \\
\hline & & 1 & 0,40 & 0,60 \\
\hline & & 2 & 0,11 & 0,89 \\
\hline & & 3 & 0,01 & 0,99 \\
\hline \multirow{9}{*}{3} & \multirow{3}{*}{1} & 0 & 0,74 & 0,26 \\
\hline & & 1 & 0,26 & 0,74 \\
\hline & & 0 & 0,55 & 0,45 \\
\hline & \multirow[t]{2}{*}{2} & 1 & 0,38 & 0,62 \\
\hline & & 2 & 0,07 & 0,93 \\
\hline & \multirow{4}{*}{3} & 0 & 0,41 & 0,59 \\
\hline & & 1 & 0,43 & 0,57 \\
\hline & & 2 & 0,15 & 0,85 \\
\hline & & 3 & 0,20 & 0,80 \\
\hline
\end{tabular}


- Persamaan rekursif.

Persamaan rekursif diperhitungkan dengan memperhitungkan ongkos - ongkos di masa yang akan datang, dapat dillihat pada persamaan berikut :

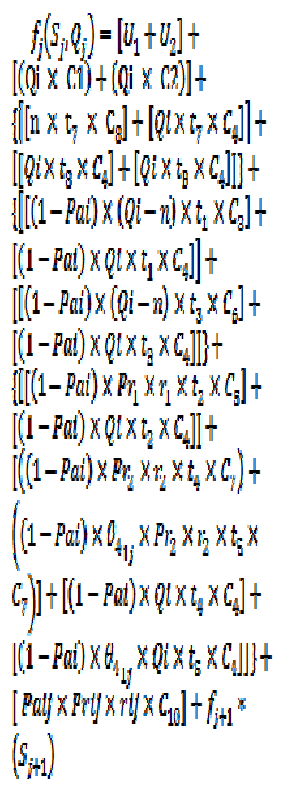

Pengujian model dilakukan untuk kondisi jumlah permintaan $(D)$ lebih besar dari kapasitas produksi $(K)$. Pengujian menggunakan set data dengan jumlah permintaan $\mathrm{D}=7$ dan kapasitas produksi $\mathrm{K}=$ 5. Nilai-nilai parameter yang digunakan seperti pada tabel 1 .
Untuk pengujian set data terdapat empat langkah pengerjaan sebagai berikut :

- Menentukan jumlah permintaan yang harus dipenuhi dan jumlah produksi di setiap run produksi ke-j dengan memperhatikan kapasitas produksi dan ukuran sampel yang digunakan. Untuk kapasitas produksi sebesar 5 unit, tingkat pemeriksaan umum II, dan jenis pemeriksaan normal untuk single samplinga didapatkan ukuran sampel $n=$ 2.

- Menghitung probabilitas kegagalan produksi untuk inspeksi sampling dan sensus. Nilai Acceptance Quality Level $(\mathrm{AQL})=6,5 \%$ maka bilangan penerimaan (Ac) sebesar 0 dan bilangan penolakan $(R e)$ sebesar 1. Probabilitas kegagalan produksi untuk inspeksi sampling seperti pada tabel 2.

Probabilitas kegagalan produksi untuk inspeksi sensus seperti pada tabel 3.

Pengujian model menggunakan proses kerja pemrograman dinamis probabilistik yang pengerjaannya secara backward procedure. Pada penelitian ini

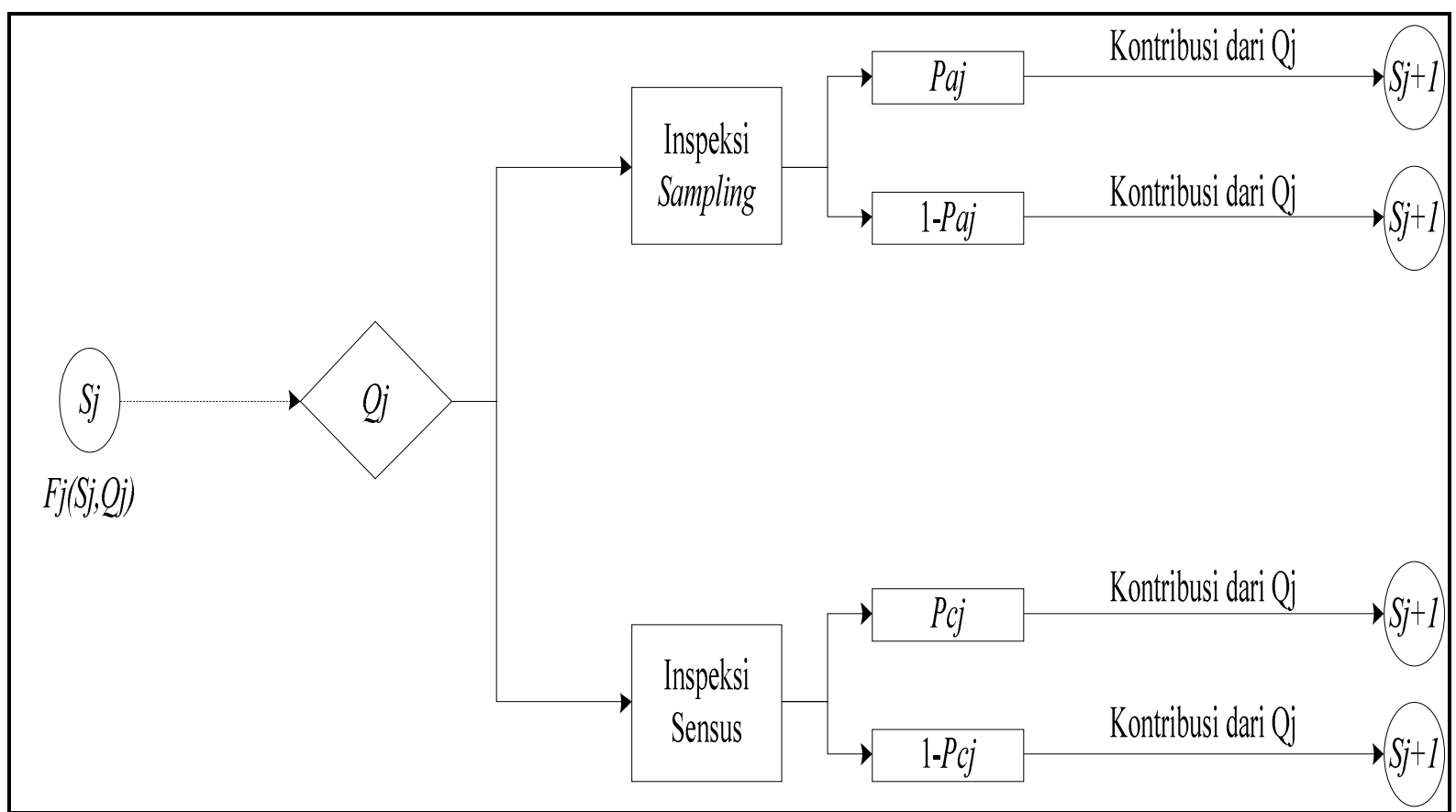

Gambar 3. Struktur Pemrograman Dinamis Probabilistik. 
- diasumsikan kebijakan run produksi yang dapat dilakukan untuk memenuhi permintaan konsumen sebanyak 3 run produksi, sehingga run produksi ke-4 merupakan biaya penalti yang harus dibayarkan ke konsumen karena tidak $j=4$ dapat memenuhi permintaan konsumen. Pada penelitian ini diasumsikan biaya penalti sebesar 100 per unit.

- Menentukan solusi optimal untuk setiap run produksi seperti pada gambar 4 .

\begin{tabular}{|c|c|}
\hline$=4$ & $f_{4}^{*}$ \\
\hline \hline$S_{4}$ & 0 \\
\hline 0 & 100 \\
\hline 1 & 200 \\
\hline 2 & 300 \\
\hline 3 & 400 \\
\hline 4 & \\
\hline
\end{tabular}

$j=3$

\begin{tabular}{|c|c|c|c|c|c|}
\hline \hline $\mathrm{Q}_{3}$ & 3 & 4 & 5 & $f^{*}$ & $a_{2}^{*}$ \\
\hline 1 & 96,07175 & - & - & 96,07175 & 3 \\
\hline 2 & 196,0718 & 122,881 & - & 122,881 & 4 \\
\hline 3 & 296,0718 & 222,881 & 158,8268 & 158,8268 & 5 \\
\hline 4 & 396,0718 & 322,881 & 258,8268 & 258,8268 & 5 \\
\hline 5 & 496,0718 & 422,881 & 358,8268 & 358,8268 & 5 \\
\hline
\end{tabular}

$j=2$

\begin{tabular}{|c|c|c|c|c|c|}
\hline $\mathrm{S}_{2} \mathrm{Q}_{2}$ & 3 & 4 & 5 & $f_{2}$ : & $q^{*}$ \\
\hline 4 & 393,2045 & 318,1814 & 242,2778 & 242,2778 & 5 \\
\hline 5 & 493,2045 & 418,1814 & 342,2778 & 342,2778 & 5 \\
\hline 6 & 493,2045 & 518,1814 & 442,2778 & 442,2778 & 5 \\
\hline
\end{tabular}

$j=1$

\begin{tabular}{|c|c|c|c|c|c|}
\hline $\mathrm{S}_{1} \mathrm{Q}_{1}$ & 3 & 4 & 5 & $f_{1} *$ & $a^{*}$ \\
\hline 7 & 490,3324 & 513,4722 & 536,3187 & 490,3324 & 3 \\
\hline
\end{tabular}

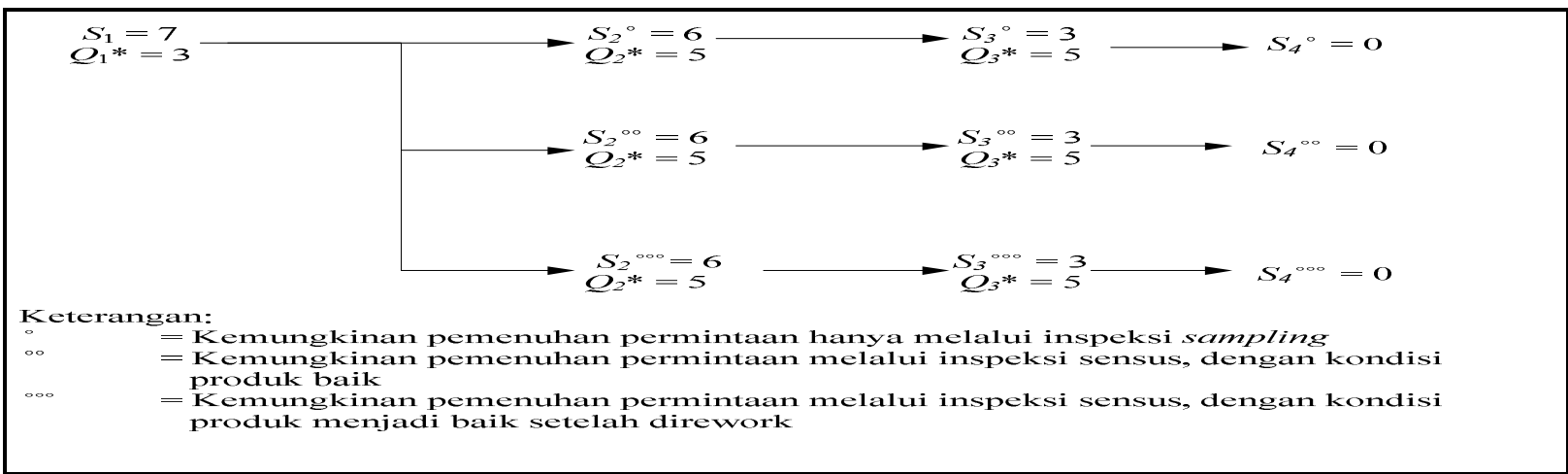

Gambar 4. Solusi Optimal Pengujian Model. 


\section{KESIMPULAN}

Kesimpulan dari penelitian yang telah dilakukan adalah sebagai berikut :

- Penelitian ini menghasilkan model optimasi lot produksi pada sistem produksi multi stage yang tidak sempurna yang disebabkan oleh deteriorasi dan kesalahan inspeksi sampling, dengan mempertimbangkan komponen biaya kualitas untuk meminimasi total biaya. Komponen biaya kualitas yang digunakan adalah biaya kegagalan internal dan kegagalan eksternal.

- Penelitian ini menggunakan dua inspeksi, yaitu inspeksi sampling dan sensus. Inspeksi sampling dapat menimbulkan kesalahan pengambilan keputusan. Inspeksi sensus dilakukan bila keputusan pada inspeksi sampling ditolak. Produk yang dinyatakan cacat pada inspeksi sensus akan melalui proses rework untuk membuatnya menjadi produk baik sebelum dikirimkan kepada konsumen.

- Besarnya demand terhadap kapasitas produksi mempengaruhi solusi optimal.

\section{DAFTAR PUSTAKA}

Astria, Vera, 2006. Tugas Akhir: Model Optimisasi Penentuan Ukuran Lot Produksi dengan Mempertimbangkan Probabilitas Kegagalan Produksi, Jurusan Teknik dan Manajemen Industri, ITENAS, Bandung.

Ben-Daya, M \& Rahim, 2003. Optimal Lotsizing, Quality Improvement and Inspection, Errors for Multistage Production Systems, International Journal of Production Research, Vol. 41 pp. 65-79.

Ebeling, C. E, 1997. Reliability and Maintenability Engineering, McGraw-Hill, Inc., Singapore.
Hiller, Frederick, S., and Gerald,J., Lieberman, 1995. Introduction To Operations Research, Mc GwawHill Companies, Inc.

Indrapriyatna, et. al, 2008 Model Penjadwalan Batch pada Satu Mesin yang Mengalami Deteriorasi untuk Minimasi Total Biaya Simpan dan Biaya Kualitas, Jurnal Teknik Industri, Vol. 10 No.1.

Johnson, Lynwood A \& Montgometry, Douglas C, 1974. Operation Research in Production Planning, Scheduling, and Inventory Control, hal 258-260.

Rosenblatt, M.J., and Lee, H. L, 1986. Economic Production Improvement and Set up Cost Reduction Processes, IIE Transactions, Vol. 18 pp. $48-55$.

Taha, H. A, 1992. Operations Research: An Intoduction, $5^{\text {th }}$ ed, Macmillan Publishing Co.,Singapore.

Tersine, R. J, 1994. Principles of Inventory and Materials Management, $4^{\text {th }} \mathrm{ed}$, Englewood Cliffs, Prentice-Hall Inc.,New Jersey.

Wibowo, Ari. 2014. Model Optimasi Lot Produksi pada Sistem Produksi yang Tidak Sempurna dengan Mempertimbangkan Komponen Biaya Kualitas untuk Meminimumkan Total Biaya. Tugas Akhir. Jurusan Teknik Industri. ITENAS. Bandung. 